\title{
Acropostite fimose em touro: relato de caso
}

Muriel Magda Lustosa Pimente $\left[{ }^{[a]}\right.$, Camila Marinho de Miranda Oliveira ${ }^{[b]}$, Regina Valéria da Cunha Dias ${ }^{[a]}$, Antônio Carlos Lopes Câmara ${ }^{[\mathrm{c}]}$, Eraldo Barbosa Calado[]

\author{
[a] Universidade Federal Rural do Semi-Árido (UFERSA), Mossoró, RN, Brasil \\ ${ }^{[b]}$ Universidade Federal Rural de Pernambuco (UFRPE), Recife, PE, Brasil

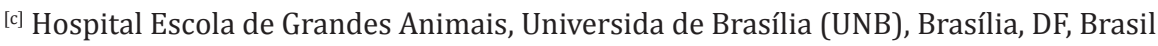

*Autor correspondente

e-mail: murielpimentel@cesmac.edu.br

\section{Resumo}

O objetivo deste trabalho foi relatar a técnica cirurgica como forma de tratamento de acropostite-fimose de um touro. Foi atendido no Setor de Grandes Animais do Hospital Veterinário (HOVET) da Universidade Federal Rural do Semi-Árido, um touro da raça Gir, com aproximadamente dois anos de idade, $380 \mathrm{~kg}$ de peso corporal, apresentando, segundo o proprietário, dificuldade de micção e inabilidade na realização da cópula. Também foi reportado o trauma como suspeita principal desencadeante do processo. 0 animal foi contido em brete de contenção para exame clínico. Os parâmetros vitais, como temperatura, frequência respiratória e cardíaca, movimentos ruminais e tempo de preenchimento capilar apresentavam-se sem alterações. Observou-se prolapso da mucosa do folheto prepucial interno e exposição permanente da parte livre do pênis. Ambas as regiões anatômicas apresentavam-se inflamadas, com áreas de fibrose e ulcerações, sendo evidenciado comprometimento isquêmico da extremidade livre do pênis, fato este associado à persistente exposição e incapacidade de retração peniana. Notou-se, também, estenose do óstio uretral, dificultando o ato de micção. Após avaliação clínica foi constatada a necessidade de intervenção cirúrgica, sendo o prognóstico considerado reservado. 0 animal foi submetido à medicação pré-anestésica, utilizando xilazina $(0,1 \mathrm{mg} / \mathrm{kg})$, sendo induzido com cetamina $(1 \mathrm{mg} / \mathrm{kg})$, e foi necessário realizar dois repiques de cetamina $(0,5 \mathrm{mg} / \mathrm{kg})$. Antes do procedimento foi realizada uma anestesia local com lidocaína acompanhada de um garrote. 0 touro ficou em decúbito lateral direito, acolchoando a região do nervo radial e do nervo ciático para evitar maiores complicações pós-cirúrgicas. Após a contenção adequada do animal, deu-se início à técnica de Wilwerth (1944), com "V" ventral. O procedimento consistiu em inserir duas pinças Kocher, uma na rafe mediana anterior e outra na posterior. Faz-se uma incisão cirúrgica com bisturi acima do ponto de transição 
da pele e mucosa prepucial de forma circular fazendo união entre as pinças. Em seguida, fez-se dissecação com tesoura ponto romba procurando identificar a mucosa prepucial, preservando todos os tecidos sadios. A dissecação provoca sangramento abundante devido à secção transversal dos vasos, os quais devem ser pinçados e ligados com vicryl (poliglactina). Retirada a área acometida, é feita a sutura da mucosa prepucial à pele, em pontos simples, separados, utilizando o mesmo fio em toda sua extensão. Neste procedimento foi realizada uma incisão em "V" na mucosa prepucial ao nível da rafe mediana posterior para facilitar a drenagem de secreções. A medicação utilizada no pós-operatório foi fenilbutazona e penicilina G procaína. 0 animal ficou ainda internado no HOVET por 24 horas, recebendo alta hospitar em seguida. Concluimos que apesar de ser uma enfermidade de grande incidência, o procedimento cirúrgico geralmente não apresenta complicações. Após 24 horas do procedimento cirúrgico, o animal já apresentava a capacidade de expor o pênis e urinar normalmente. 